\title{
In Memoriam Prof. Dr. M.A.P. Meilink-Roelofsz
}

(The Hague, the Netherlands, Dec. 6, 1905 - Sept. 23, 1988)*

Marie Antoinette Petronella Meilink-Roelofsz was born at The Hague on the 6th of December 1905. Her career as an archivist and a scholar was far from easy. Starting off as an unpaid volunteer for seven years (1930-1937) at the 'Algemeen Rijksarchief' (National Archives) at The Hague, she was officially appointed as a juniorarchivist at the National Archives (First Section: archives of the Eastand West India Companies) only in 1937. Between 1947 and 1951 she studied history at the University of Amsterdam, under the inspiring guidance of such great Dutch historians as Jacques Presser and Jan Romein. Her husband, the medievalist Dr. Petrus Anne Meilink (also attached at the National Archives) turned out to be her inspirator par excellence. It was he who directed her towards the work which was to be her 'magnum opus', her doctoral dissertation (under Romein), published in 1962: Asian Trade and European Influence in the Indonesian Archipelago between 1500 and about 1630, bringing her international fame. This work, however, was not her first book; in 1943 a very detailed study on the Dutch in Malabar (De Vestiging der Nederlanders ter kuste van Malabar) had been published. Between 1964 and 1971 she was to be the 'Rijksarchivaris' of the First Section of the National Archives, being only the second woman in Holland having reached a similar position. Scholars from all over the world owe to her two indispensable research-tools: a Calendar of the bulky 'Overgekomen Brieven en Papieren van Batavia', made under her direction, while she herself completed the gigantic task of making the Inventory of the Archives of the famous Dutch East India Company (VOC), an Archivist's Masterpiece. From the lst of September 1970 she started another career at Leiden University, as Professor of 'The History of Western-European Expansion Overseas'. This was not to be teaching and promoting research in the old-fashioned, Europe-centered Colonial History-style. Prof. Meilink tried to illuminate the subjectmatter both from an Asian as well as from a European perspective. 
To her students as well as to the various audiences elsewhere she was able to convey the importance of material of the VOC-Archives for the history of the Asian civilisations themselves, urging people to venture upon unknown but fascinating fields of research. It was Mrs. Meilink's idea to coordinate research in this field in the Netherlands on a multidisciplinary basis between the different Dutch universities. From the early thirties, she started to help students and scholars visiting the National Archives, guiding them in their research in the archives. She slowly, but steadily established an international status, while stressing the importance of the VOC-archives for a worldwide public. She corresponded widely and the was always prepared to help students. She paid long, official visits to the East, particularly to Japan and to Indonesia in 1964 and the the West (Surinam and the Antilles) in 1965. Long-standing relationships with colleagues like C.R.Boxer, Holden Furber, Mrs. Sumartini, the late Iwao Seiichi and Nagazumi Akira meant a great deal to her. Mrs. Meilink was a scholar and a human being who continued during her long life to be very demanding, in the first place of herself, but also of others, considering high quality both of research and publications in her field, and of human behaviour as such, to be of foremost importance. Until the very end of her life she was interested in, and worried about the future of the younger generation and of world affairs at large. She will be respected and well remembered by many of us in East and West.

Frank Lequin

* In Itnerario of 1977, an interview with Professor Meilink was published. 